\title{
EL MOVIMIENTO SOCIAL DE LA UNIÓN CAMPESINA EMILIANO ZAPATA VIVE EN DEFENSA DEL TERRITORIO Y LOS DESAFIOS EN LA CONSTRUCCIÓN DE UN DESARROLLO RURAL ALTERNATIVO
}

\section{THE UNIÓN CAMPESINA EMILIANO ZAPATA VIVE SOCIAL MOVEMENT IN DEFENSE OF THE TERRITORY AND THE CHALLENGES IN THE CONSTRUCTION OF AN ALTERNATIVE RURAL DEVELOPMENT}

\author{
Javier Ramírez-Juárez \\ Colegio de Postgraduados, Campus Puebla, Estado de Puebla (rjavier@colpos.mx)
}

\begin{abstract}
RESUMEN
El gobierno del estado de Puebla diseñó el Proyecto Millenium con el objetivo de promover la urbanización y la industrialización en alrededor de cinco mil hectáreas, en la región TepeacaTecamachalco e inició la compra de tierras para la construcción de una carretera en el año 2000. A este proceso se resistieron los campesinos y habitantes de la región formando un movimiento social de la Unión Campesina Emiliano Zapata Vive. El trabajo analiza los elementos constituyentes de la identidad colectiva, el conflicto y la contribución del movimiento social a un desarrollo rural alternativo. El indagar sobre la identidad colectiva, especialmente sobre el modo de vida campesino aporta elementos sobre el papel de la agricultura en su reproducción social, en un marco de exclusión y desvaloración económica y social de este sector social.
\end{abstract}

Palabras clave: campesinos, conflicto social, identidad colectiva, modo de vida, Proyecto Millenium.

\section{INTRODUCCIÓN}

$\mathrm{E}$ n el marco del modelo neoliberal, el gobierno del estado de Puebla, desde principios de la década de 1990, ha promovido una intensa reorganización territorial y posicionamiento de la Ciudad de Puebla en la economía global. Este proceso se expresa en la creación de desarrollos inmobiliarios, parques industriales, la construcción de infraestructura carretera e hídrica, que transforman el paisaje y la expansión del espacio metropolitano con bordes difusos sobre tierras de propiedad social. Esta

* Autor responsable * Author for correspondence. Recibido: octubre, 2017. Aprobado: febrero, 2018. Publicado como ARTÍCULO en ASyD 18: 49-66. 2021.
ABSTRACT

The government of the state of Puebla designed the Proyecto Millenium with the objective of promoting the urbanization and industrialization in around five thousand hectares, in the Tepeaca-Tecamachalco region, and began purchasing lands for the construction of a highway in the year 2000. Peasants and residents of the region resisted this process and formed the social movement by the Unión Campesina Emiliano Zapata Vive. The study analyzes the elements that constitute collective identity, conflict and contribution of the social movement to an alternative rural development. Inquiring about the collective identity, especially about the peasant lifestyle, contributes elements regarding the role of agriculture in their social reproduction, within a framework of exclusion, and economic and social devaluation of this social sector.

Key words: peasants, social conflict, collective identity, lifestyle, Proyecto Millenium.

\section{INTRODUCTION}

$\mathrm{I}$ $\mathrm{n}$ the framework of the Neoliberal model, the government of the state of Puebla has promoted since the 1990s, an intense territorial reorganization and positioning of the city of Puebla in the global economy. This process is expressed in the creation of real estate development, industrial parks, construction of highway and water infrastructure, which transform the landscape and expand the metropolitan space with diffuse edges on the lands of social property. This dynamic disrupts the relationships between society, economy and territory, by suggesting the commercialization of the land and generation of conflicts over its use. 
dinámica trastoca las relaciones entre sociedad, economía y territorio, al plantear la mercantilización del suelo y la generación de conflictos por su uso.

El entorno rural de la ciudad de Puebla ha sido escenario de una intensa movilización social de los campesinos y habitantes del medio rural para defender sus recursos, tierra y agua. Entre los movimientos más destacados, por su naturaleza y magnitud, se encuentra el de los campesinos de la región TepeacaTacamachalco que se opusieron a la decisión del gobierno del estado de Puebla de ejecutar el Proyecto Millenium (PM) en el año 2000. El PM consideró la creación de infraestructura carretera, desarrollo inmobiliario e industrial en alrededor de cinco mil hectáreas propiedad de ejidatarios y pequeños propietarios pertenecientes a trece municipios de la región.

El PM fue rechazado por los campesinos y habitantes del medio rural, protestas y movilizaciones fueron las respuestas inmediatas hasta la formación de un movimiento social (MS), que se constituyó en la Unión Campesina Emiliano Zapata Vive (UCEZV). Los campesinos definieron, en medio del conflicto, que el PM afectaría su modo de vida basado en la agricultura, interpretación sobre el que construyeron una identidad colectiva, un consenso regional de rechazo a la propuesta gubernamental, la defensa del territorio y la formulación de un proyecto de desarrollo rural territorial alternativo al planteado por el PM.

Zepeda (2017) en una revisión sobre los MS en Latinoamérica sostiene que la oposición y resistencia al neoliberalismo ha sido principalmente en el área rural y los sectores urbanos rezagados, condición válida para el caso de México. Son MS emergentes, que como el caso de la UCEZV surgen por la imposición neoliberal de programas, proyectos y reformas excluyentes social, económica y políticamente.

El indagar sobre los elementos de la resistencia campesina a proyectos de modernización, especialmente sobre el modo de vida elegido por los participantes en el movimiento social aporta elementos sobre la valoración e importancia de la agricultura, de la tierra y agua, en la reproducción social de los campesinos, en un marco de exclusión y desvaloración económica y social del sector, lo cual permitirá acercarse a comprender la naturaleza del conflicto. Pero también a preguntarnos sobre los desafíos en la construcción de un desarrollo rural alternativo, que se gesta en la lucha por la democracia social y política
The rural environment of the city of Puebla has been the scenario of an intense social mobilization of the peasants and residents of rural areas to defend their resources, land and water. Among the most prominent movements, because of its nature and magnitude, is the one of peasants of the TepeacaTecamachalco region that opposed the decision of the state of Puebla's government to execute the Proyecto Millenium (PM) in the year 2000. The PM considered the creation of highway infrastructure, real estate and industrial development in around five thousand hectares property of ejidatarios and small owners who belong to thirteen municipalities of the region.

The PM was rejected by peasants and residents of the rural areas; the immediate responses were protests and mobilizations, until the formation of a social movement (SM), which was constituted into the Unión Campesina Emiliano Zapata Vive (UCEZV). Peasants defined, in the midst of the conflict, that the PM would affect their lifestyle based on agriculture, interpretation about which they built a collective identity, a regional consensus of rejection to the governmental proposal, the defense of the territory, and the formulation of an alternative territorial rural development project than the one suggested by the PM.

Zepeda (2017), in a review of SM in Latin America, argues that opposition and resistance to Neoliberalism have taken place primarily in the rural area and the backward urban sectors, valid condition for the case of Mexico. They are emergent SM, which as the case of the UCEZV arise from the Neoliberal imposition of programs, projects and reforms that are socially, economically and politically discriminatory. Inquiring about the elements of peasant resistance to modernization projects, especially about the lifestyle chosen by participants in social movements, contributes elements about the valuation and importance of agriculture, land and water, in the social reproduction of peasants, within a framework of exclusion and economic and social devaluation of the sector, which will allow beginning to understand the nature of the conflict. However, also to inquire about the challenges in the construction of an alternative rural development, which arises in the struggle for the social and political democracy of the UCEZV. Both aspects, the role of agriculture and of rural development, are fully current in the struggle 
de la UCEZV. Ambos aspectos, del papel de la agricultura y del desarrollo rural, son plenamente vigentes en la lucha contra la exclusión social y política, de la pobreza rural que viven amplios sectores de la población en México. Pues si bien el MS de la UCEZV protagonizó el conflicto con el gobierno del estado de Puebla a inicios de la década del 2000 las lecciones y los desafíos siguen imperantes. En este marco, el objetivo del trabajo es analizar los elementos constituyentes de la identidad colectiva, el conflicto y la contribución del movimiento social a un desarrollo rural alternativo.

Para el estudio se parte de la formulación de Melucci (1999) sobre movimiento social, como formas de acción colectiva, que comprende las siguientes dimensiones analíticas: a) basada en la solidaridad; b) que desarrolló un conflicto; y c) que rompe los límites del sistema en que ocurre la acción. La dimensión de la solidaridad alude a la capacidad de los actores para compartir una identidad colectiva; el conflicto refiere a la relación contenciosa entre actores opuestos luchando por los mismos recursos. Los límites del sistema significa "la acción que sobrepasa el rango de variaciones que un sistema puede tolerar, sin cambiar su estructura" (Melucci, 1999: 57).

A partir del anterior planteamiento, se consultaron diversas referencias y documentos hemerográficos, estadísticos e históricos; se realizó trabajo de campo, utilizando métodos cualitativos con entrevistas semiestructuradas, a diversos actores sociales participantes en la UCEZV, grupos de discusión y la observación participante. El trabajo de campo ha comprendido una relación cercana con líderes y participantes del movimiento social entre 2005 y 2016, que permitió captar y analizar las potencialidades de transformación del sujeto desde su perspectiva.

\section{La región del conflicto y El Proyecto Milenium}

La región Tepeca-Tecamachalco se encuentra ubicada en el centro oriente del estado de Puebla, a $2100 \mathrm{msnm}$, limita al norte con las estribaciones meridionales del volcán La Malinche, al sur con la sierra del Tentzo; al oeste por los llanos de San Andrés y al oeste por el valle de Puebla. Presenta un clima templado subhúmedo con lluvias en verano, con una precipitación promedio de $750 \mathrm{~mm}$. Comprende los municipios a Tepeca, Tecamachalco, Tepeyehualco, against social and political exclusion, from the rural poverty that wide sectors of the population in Mexico experience. For, although the UCEZV SM was a protagonist in the conflict with the state of Puebla's government at the beginning of the 2000s, the lessons and the challenges continue to prevail. In this framework, the objective of this study is to analyze the elements that constitute collective identity, conflict and contribution of the social movement to an alternative rural development.

The starting point for the study is the formulation by Melucci (1999) about social movements as a form of collective action, which includes the following analytical dimensions: a) based on solidarity; b) which developed a conflict; and c) which break the limits of the system where the action happens. The dimension of solidarity refers to the ability of the actors to share a collective identity; the conflict refers to the contentious relationship between opposing actors struggling over the same resources. The limits of the system means: "the action that exceeds the range of variations that a system can tolerate, without changing its structure" (Melucci, 1999: 57).

From this approach, various references and newspapers were consulted, as well as statistical and historical documents; field work was carried out with various social actors who participate in UCEZV, using qualitative methods with semi-structured interviews, discussion groups and participant observation. Field work included a close relationship with leaders and participants of the social movement between 2005 and 2015, which allowed capturing and analyzing the potentialities of transformation of the subject from their perspective.

\section{The region of conflict and the Proyecto Millenium}

The Tepeca-Tecamachalco region is located in the center-eastern part of the state of Puebla, at 2100 masl; it borders to the north with the southern foothills of the La Malinche volcano, south with the Tentzo sierra, west with the San Andrés plains, and west with the valley of Puebla. It presents a sub-humid temperate climate with summer rains, with an average precipitation of $750 \mathrm{~mm}$. It covers the municipalities of Tepeca, Tecamachalco, Tepeyehualco, Tochtepec, Acatzingo, Tecali, Cuautinchán, Hueyotlipan, Huixcolotla, Tlanepantla and Mixtla, which 
Tochtepec, Acatzingo, Tecali, Cuautinchán, Hueyotlipan, Huixcolotla, Tlanepantla y Mixtla, que integran una región estratégica por su posición y vinculación geográfica, al configurarse como un cruce de comunicación hacia el sureste mexicano, el pacífico, el golfo y el centro del país, con importantes recursos de tierra, agua y clima, propicios para la producción agrícola.

Entre el siglo dieciocho y veintiuno se distinguen varios sistemas agrarios, en la región Tepeaca-Tecamachalco, asociados al uso, a la forma de apropiación material, simbólica y control territorial, que le han conferido características propias (Ramírez, 2009). Durante la Colonia se construyó un sistema agrario de grandes concentraciones de tierra, dedicado a la producción de maíz y trigo. Hacia finales del siglo XVIII existían más de 400 haciendas dedicadas a la producción de maíz, trigo, ovinos y porcinos, orientadas principalmente al abasto de Puebla y secundariamente a Veracruz (Garavaglia y Grosso, 1994). Este sistema generó conflictos por las tierras entre indios y españoles (Olivera, 1978), pero se mantuvo sin grandes cambios durante la independencia hasta inicios del siglo XX (Lomelí, 2001).

En el período de la revolución mexicana no se realizaron expropiaciones y repartos de tierra de las haciendas, es hasta finales de la década de 1920 que los peones iniciaron la demanda y luchas por la tierra (Nickel, 2004). Las anteriores acciones culminaron con la reforma agraria, en la década de 1930, que transformó el sistema agrario de grandes explotaciones agrarias a pequeñas unidades productivas, basadas en el trabajo familiar, dedicada a la producción de maíz, frijol, trigo y ganado. Políticamente, con el ejido, el campesinado fue subordinado al control corporativo del Estado mexicano, a través de la Confederación Nacional Campesina (CNC).

El sistema agrario de pequeñas explotaciones permitió al campesinado su reproducción social y económica, pero hacia la década de 1970, en el contexto de la desvalorización de las actividades agrícolas, especialmente de la producción del maíz, iniciaron acciones sociales para mejorar sus sistemas productivos y la diversificación agrícola, con la construcción de unidades de riego, que permitió la introducción de cultivos con mayor rentabilidad económica como son las hortalizas y los forrajes. Se calcula que en la región existen alrededor de 18000 ha irrigadas, gestionadas por la organización social de los campesinos. integrates a strategic region because of its position and geographic correlation, when shaped as a communication crossing toward the Mexican southeast, the pacific, the gulf zone and the center of the country, with important resources of land, water and climate, favorable for agricultural production.

Several agrarian systems were differentiated between the $18^{\text {th }}$ and $21^{\text {st }}$ century, in the TepeacaTecamachalco region, associated to the use and to the form of material, symbolic and territorial control appropriation, which has conferred to it characteristics of its own (Ramírez, 2009). During the Colony, an agrarian system of large land concentrations was built, devoted to the production of maize and wheat. Toward the end of the $18^{\text {th }}$ century, there were more than 400 haciendas devoted to the production of maize, wheat, sheep and pigs, directed primarily to supply in Puebla and secondarily to Veracruz (Garavaglia and Grosso, 1994). This system generated conflicts between indigenous and Spanish people over the lands (Olivera, 1978), although it was kept without great changes during the Independence and until the beginning of the $20^{\text {th }}$ century (Lomelí, 2001).

In the period of the Mexican Revolution, expropriations and land distribution were not carried out; it was not until the end of the 1920s when workers started the demand and struggle over land (Nickel, 2004). These actions culminated with the agrarian reform, in the decade of the 1930s, which transformed the agrarian system from large agrarian exploitations to small-scale productive units, based on family labor, devoted to the production of maize, bean, wheat and livestock. Politically, with the ejido, peasants were subordinate to the corporate control of the Mexican State, through the National Peasant Confederation (Confederación Nacional Campesina, CNC).

The agrarian system of small-scale farms allowed peasants their social and economic reproduction, but toward the decade of the 1970s, in the context of the devaluation of agricultural activities, especially of maize production, social actions began to improve their productive systems and for agricultural diversification, with the construction of irrigation units, which allowed the introduction of crops with higher economic profitability such as vegetables and fodders. It is calculated that in the region there are around 18000 irrigated hectares, managed by the peasants' social organization. 
En la superficie de riego de la región se siembran alrededor de cuarenta cultivos cíclicos y perennes. En 2005 se sembraron 44987 ha, 46.2\% en riego y $53.8 \%$ en temporal. El valor total de la producción fue cercano a 438 millones de pesos, de los cuales el riego aportó $81 \%$ y el temporal 19\% (SIAP, 2006). Las hortalizas, por su aporte económico, comandan la producción, seguidas por los forrajes, los granos básicos, las flores y los frutales. Es indudable el aporte del riego a la economía regional, además la agricultura genera trabajo y demanda una amplia gama de servicios.

Bajo el anterior contexto de la agricultura campesina, el gobierno del estado de Puebla promovió la instrumentación del PM en el año 2000. De acuerdo con Hernández (2009), el PM formó parte del Programa de Desarrollo Regional Puebla 2000, para convertir la región centro-oriente del estado en un polo de crecimiento económico con la construcción de parques industriales, zonas residenciales, de ocio, mineras, turísticas, ecológicas, así como de infraestructura carretera, que en conjunto requerían cerca de cinco mil hectáreas. El PM consideró dieciocho comunidades pertenecientes a los municipios de Tecamachalco, Tochtepec, Tecali, Cuautinchán, Hueyotlipan, Tlanepantla, Tepeaca y Mixtla. La región elegida para instrumentar el PM tiene una posición geográfica estratégica por su conectividad hacia el puerto de Veracruz y el pacífico con el puerto de Acapulco. El objetivo del PM fue:

"maximizar la dinámica de producción en el ámbito regional, vinculando las economías rurales a las urbanas en franca complementariedad intermunicipal; y promover el ordenamiento territorial de las actividades económicas y de la población conforme a las potencialidades de las regiones con el fin de mejorar la calidad de vida de sus habitantes, proponiendo acciones de inversión que incentiven el arraigo regional y reinviertan el actual patrón de concentración-dispersión que se viene presentando en el estado debido al fenómeno migratorio actual" (SCT, 2001:1).

El PM tiene sus coordenadas en el neoliberalismo, el cual considera "que la mejor manera de promover el bienestar del ser humano consiste en no restringir el libre desarrollo de las capacidades y de las libertades empresariales del individuo dentro de un
In the irrigation surface of the region, around forty cyclic and perennial crops are sown. In 2005, 44987 ha were sown, $46.2 \%$ under irrigation and $53.8 \%$ rainfed. The total value of the production was close to 438 million pesos, of which irrigation contributed $81 \%$ and rainfed $19 \%$ (SIAP, 2006). The vegetables, due to their economic contribution, command the production, followed by fodders, basic grains, flowers and fruits. It is undoubtedly the contribution of irrigation to the regional economy, in addition to agriculture generating work and demanding a broad range of services.

Under this context of peasant agriculture, the government of the state of Puebla promoted the implementation of the PM in 2000. According to Hernández (2009), the PM was part of the Puebla's Regional Development Program in 2000, to convert the center-eastern region of the state into a pole of economic growth with the construction of industrial parks, and residential, leisure, mining, tourism, ecological zones, as well as highway infrastructure, which as a whole required close to five thousand hectares. The PM considered eighteen communities belonging to the municipalities of Tecamachalco, Tochtepec, Tecali, Cuautinchán, Hueyotlipan, Tlanepantla, Tepeaca and Mixtla. The region selected to implement the PM has a strategic geographic position due to the connectivity toward the port of Veracruz and the Pacific with the port of Acapulco. The objective of the PM was:

"to maximize the production dynamic in the regional sphere, connecting the rural economies to the urban ones in clear inter-municipal complementarity; and to promote the territorial ordering of economic activities and of the population based on the potentialities of the regions with the aim of improving the quality of life of its residents, suggesting investment actions that incentivize regional rooting and reverting the current pattern of concentration-dispersion that has been present in the state due to the current migratory phenomenon" (SCT, 2001:1).

The PM has its coordinates in Neoliberalism, which considers "that the best way of promoting the wellbeing of human beings consists in not restricting the free development of abilities and of entrepreneurial liberties of the individual within an institutional 
marco institucional caracterizado por derechos de propiedad privada fuerte, mercado libres y libertad de comercio" (Harvey, 2007: 6), el Estado tendría la responsabilidad de crear y garantizar estas condiciones (Harvey, 2007).

El PM en su formulación y objetivo representó una concepción de reorganización territorial de la región centro oriente del estado de Puebla, bajo las siguientes orientaciones:

1. El gobierno del estado de Puebla asume la tarea de crear las condiciones para la inserción del capital inmobiliario e industrial. Se establece una alianza entre agentes privados y el gobierno del estado para diseñar pautas en la organización territorial, en una región con ventajas y posicionamiento geográfico estratégico.

2. La organización territorial y actividades económicas planteadas por el PM no consideran a la agricultura y excluye al campesinado. El PM en su concepción es un espacio de representación, radicalmente diferente al construido socialmente por el campesinado.

3. En su diseño y ejecución el PM expresa a un Estado autoritario y coercitivo que trata de imponer su concepción de organización del territorio y del desarrollo.

El PM inició con la compra de tierras a los campesinos para la construcción de una carretera, que conectaría a Puebla con Tecamachalco, por la Secretaría de Comunicaciones y Transportes (SCT) del estado de Puebla. La compra de la tierra fue a través de la presión y chantaje, se pagó a 60 centavos el metro cuadrado de la tierra ejidal o de pequeña propiedad. El resultado fue la compra de $70 \%$ de la superficie total requerida para la construcción de la carretera. Durante el ańo 2000, los funcionarios del gobierno del estado de Puebla negaron sistemáticamente la existencia del PM, en la prensa y frente a los representantes de la UCEZV.

\section{El modo de vida campesino e identidad en la formación del sujeto social}

El modo de vida campesino de la región del PM se fue construyendo durante la compra de tierras y el conflicto entre la UCEZV y el gobierno del estado de Puebla. Bebbington (1999) considera el modo de framework characterized by strong private property rights, free markets and free trade" (Harvey, 2007: 6), the State would have the responsibility of creating and guaranteeing these conditions (Harvey, 2007). The PM in its formulation and objective represented a conception of territorial reorganization of the center-eastern region of the state of Puebla, under the following positions:

1. The government of the state of Puebla takes on the task of creating the conditions for insertion into the real estate and industrial capital. An alliance between private agents and the state's government was established to design standards in the territorial organization, in a region with advantages and strategic geographic positioning.

2. The territorial organization and economic activities suggested by the PM do not consider agriculture and exclude peasants. The PM in its conception is a space of representation, radically different from the one socially constructed by peasants.

3. In its design and execution, the PM expresses an authoritarian and coercive State that attempts to impose its conception of territory organization and development.

The PM began with the purchase of lands from peasants for the construction of a highway that would connect Puebla with Tecamachalco, by the Ministry of Communication and Transport (Secretaria de Comunicaciones $y$ Transportes, SCT) of the state of Puebla. Land purchasing was done through pressure and blackmail, paid at 60 cents per square meter of the ejido or small property land. The result was the purchase of $70 \%$ of the total surface required for the construction of the highway. During the year 2000, government agents from the state of Puebla systematically denied the existence of the PM, in the press and in front of the UCEZV representatives.

\section{The peasant lifestyle and identity in the formation of the social subject}

The peasant lifestyle of the PM region was gradually constructed during the purchase of lands and the conflict between the UCEZV and the government of the state of Puebla. Bebbington (1999) considers the lifestyle as the various forms 
vida como las diversas formas y recursos a través de las cuales las personas se ganan la vida y construyen sus mundos; formas y recursos sustentados, en la región, en la tierra, el riego y la agricultura que serían afectados de ejecutarse el PM.

Los campesinos que participan en el MS manifestaron, durante el trabajo de campo, varios elementos acerca de la importancia y valoración de la agricultura entre los que destacan: la producción de alimentos para el autoconsumo, la producción de hortalizas que permite la obtención de recursos económicos y la generación de empleo. Actividades y recursos que les permiten cierta estabilidad y certidumbre. Los campesinos elaboran una valoración social y económica de la agricultura en relación y comparativamente a la posibilidad de laborar en la industria, que estiman de incierta y de insuficiente en la obtención de ingresos y salarios, valoración sintetizada en el siguiente testimonio:

"las autoridades han ofrecido 60 mil pesos por cada hectárea, pese a que cada año tan sólo por la siembra de alfalfa obtiene 24 mil pesos. Eso es sólo con un cultivo, en tres ańos con la alfalfa sacamos lo que el gobierno nos quiere pagar. En caso de vender sólo nos quedaría el recuerdo de que fueron nuestras tierras y mientras de qué vivimos... Con los sueldos de las maquiladoras no vivimos, si supiéramos que con eso podríamos mantener a nuestra familia pues le entraríamos, pero allí pagan el salario mínimo y además, nosotros no sabemos trabajar en las fábricas, toda la vida hemos sido campesinos. ¿Qué nos ofrecen a cambio de nuestras tierras de las que sacamos para vivir? Sólo miseria”. Comisariado ejidal de Santa Rosa, La Jornada de Oriente, 19 de marzo de 2001.

El énfasis de los campesinos sobre la importancia de la agricultura tiene un sustento económico y social, afianzada por la incertidumbre y la desconfianza. Expresa un cálculo entre los ingresos de la agricultura y los posibles salarios en la industria, a partir de la cual elaboran una conclusión sencilla y relevante: la posesión de la tierra y la agricultura ofrece certidumbre y un modo de vida ${ }^{1}$. Condición social que es amenazada por el PM, que los llevaría a perder su base alimentaria, el empleo, la tierra y a la pobreza. and resources through which people earn a living and build their worlds; forms and resources sustained, in the region, by land, irrigation and agriculture that would be affected if the PM were to be executed.

During the field work, the peasants who participate in the SM manifested several elements about the importance and valuation of agriculture, among which the following stand out: food production for auto-consumption, vegetable production that allows obtaining economic resources, and employment generation. These activities and resources allow certain stability and certainty. The peasants elaborate a social and economic valuation of agriculture in relation and comparatively to the possibility of working in the industry, which they estimate as uncertain and insufficient in obtaining income and salaries. The valuation is synthesized in the following testimony:

"the authorities have offered 60 thousand pesos per hectare, although each year just from sowing alfalfa they obtain 24 thousand pesos. That is with just one crop; in three years with alfalfa we get what the government wants to pay. In the case of selling we would only have left the memory of what our lands were and in the meantime, what will we live on... With the salaries of the maquiladoras we cannot survive, if we knew that we could sustain our family with this then we would be all in, but they pay the minimum salary and, in addition, we do not know how to work in the factories, we have been peasants all our lives. What do they offer in exchange for our lands that we use for our livelihoods? Only misery". Comisariado ejidal de Santa Rosa, La Jornada de Oriente, March 19, 2001

The emphasis of peasants on the importance of agriculture has an economic and social basis, secured by uncertainty and mistrust. It expresses a calculation between the income from agriculture and the possible salaries in the industry, from which they elaborate a simple and relevant conclusion: land ownership and agriculture offer certainty and a livelihood ${ }^{1}$. This social condition is threatened by the PM, which would lead them to lose their food base, employment, land and poverty.

Lifestyle is an expression that consistently refers to peasants to signal agriculture, the resources that 
La forma de vida es una expresión que consistentemente refieren los campesinos para señalar a la agricultura, los recursos que la favorecen: la tierra, el agua y el trabajo; los alimentos e ingresos; las relaciones sociales que establecen en la producción y el comercio. Estos elementos les permiten cierta autonomía económica y social en el ámbito de las explotaciones agrícolas, de relaciones e intercambio que se reproducen espacialmente, construyendo socialmente el territorio.

El modo de vida elaborado por los campesinos surge de la valoración de la agricultura y los recursos base de su reproducción social, en confrontación con el PM, valoración que se convierte en una crítica social y económica al PM. El modo de vida campesinos al estar vinculado a recursos materiales e inmateriales, se produce el espacio de un modo de vida campesino. En palabras de Lefebvre "se pasa de la producción en el espacio a la producción del espacio" (Lefebvre, 1961: 219). Así, lo que está en juego en el conflicto entre la UCEZV y el gobierno del estado de Puebla son las consecuencias territoriales del PM en el modo de vida de los campesinos.

El modo de vida elegido por el campesinado, constituye el primer paso en la construcción de la identidad, que paulatinamente se transforma en colectiva. La identidad colectiva no es una esencia, no es resultado natural de condiciones objetivas (Porto, 2001), es un proceso social que va definiendo un "nosotros" y un "ellos", es decir una alteridad, que surge en medio del conflicto, de la negociación, de la valoración y confrontación del modo de vida campesino con el PM. La identidad colectiva, de acuerdo con Giménez (2000: 60) "están constituidas por individuos vinculados entre sí por un sentimiento común de pertenencia y una orientación común de acción”.

La UCEZV se constituye con la participación de 13 comunidades y alrededor de 1500 campesinos, el 26 de noviembre del ańo 2000, vertebrada por la participación e integración de las unidades de riego y autoridades ejidales, de las cuales surgen los principales liderazgos. Es significativo que la reunión para su constitución se realizó en una unidad de riego, donde se encuentran los campesinos con mayor dinamismo económico y experiencia organizativa.

La forma organizativa que adopta la UCEZV es la de una red social, con la participación de núcleos o sectores de las comunidades rurales, que nombran representantes para la formación de una mesa directiva favor it: land, water and work; food and income; social relationships that they establish in production and commerce. These elements allow them certain economic and social autonomy in the scope of agricultural exploitations, relationships and exchange that are reproduced spatially, socially building the territory.

The lifestyle elaborated by peasants emerges from the valuation of agriculture and the base resources for their social reproduction, in confrontation with the PM; this valuation becomes a social and economic criticism of the PM. Since peasants are connected to material and immaterial resources in their lifestyle, the space of a peasant lifestyle is produced. In words by Lefebvre: "they go from production in the space to production of the space" (Lefebvre, 1961: 219). Thus, what is at stake in the conflict between UCEZV and the government of the state of Puebla are the territorial consequences of the PM in the lifestyle of peasants.

The lifestyle chosen by peasants constitutes the first step in the construction of identity, which gradually transforms into the collective. Collective identity is not in essence a natural result of objective conditions (Porto, 2001), it is a social process that defines an "us" and "them"; that is, an otherness that emerges in the midst of conflict, negotiation, valuation and confrontation of the peasant lifestyle with the PM. Collective identity, according to Giménez (2000: 60) "is constituted by individuals linked between one another by a common feeling of belonging and a common orientation for action".

UCEZV is constituted with the participation of 13 communities and around 1,500 peasants, on November 26, 2000; it was backed by the participation and integration of the irrigation units and ejido authorities, from which the main leaderships arise. It is significant that the meeting for its constitution was carried out in an irrigation unit, where peasants with greater economic dynamism and organizational experience are found.

The organizational form that UCEZV adopts is that of a social network, with the participation of nuclei or sectors of the rural communities that name representatives for the formation of a directive board made up by a president, secretary and treasurer. They delegate the representation to these, but with a broad social participation system based on community assemblies to inform, analyze and make decisions, 
compuesta por un presidente, secretario y tesorero. En ellos delegan la representación pero con un sistema de participación social amplio, a partir de asambleas comunitarias para informar, analizar y tomar decisiones, entre ellas la de movilización. Se establecen como principios del movimiento social la no dependencia de ningún partido político y la negativa a negociar o ceder en la venta de la tierra. La demanda que plantea la UCEVZ es la cancelación del PM y la devolución de la tierra comprada por la SCT.

La UCEZV constituye un sujeto social compuesto por una heterogeneidad social, identitariamente asociados a Emiliano Zapata, general de la Revolución Mexicana de 1910. Emiliano Zapata para los campesinos de la UCEZV "representa la lucha de los desprotegidos contra los intereses de la clase favorecida; es también — sobre todo a partir del levantamiento zapatista en Chiapas - una lucha por la dignidad; en favor de la tierra" (Hernández et al., 2013: 101).

Con la constitución de la UCEZV se configura la creación de una identidad colectiva y un consenso de una diversidad de agentes sociales de rechazo al PM, sobre la base de lazos de amistad, solidaridad y familiar en el ámbito de las comunidades rurales. La participación social en el MS no se circunscribe a los campesinos, participan activamente ejidatarios, pequeños propietarios, avecindados, jornaleros, pequeños comerciantes, hombres y mujeres que hacen suya la demanda de la cancelación del PM. Estos sectores sociales comparten el espacio de vida de los campesinos con los que mantienen relaciones y cierta cohesión social como expresión de prácticas comunitarias y organizativas locales en la formación de un sentido de lugar; pero también por ser partícipes de formas de dominio y exclusión social y política, comparten el sentimiento de un gobierno autoritario, indignados por la forma de actuación del gobierno.

Un factor que anima y amplía la participación social en el MS es la demostración de la existencia del $\mathrm{PM}$, que como se señaló al principio fue sistemáticamente negado por el gobierno del estado de Puebla. En abril de 2001 miembros de la UCEZV obtienen un documento de la SCT en donde se expone las propuestas estratégicas de desarrollo regional sustentable del PM, que ciertamente considera el desarrollo inmobiliario, turístico e industrial en la región.

La confirmación de la existencia del PM, la forma autoritaria de ejecutarlo y los precios irrisorios que se pagaba por la tierra profundiza el rechazo al PM y la among them on mobilization. As principles of the social movement, the following were established: non-dependency on any political party and the negative to negotiate or concede in selling the land. The demand that the UCEVZ suggests is the cancellation of the PM and the return of the land purchased by the SCT.

The UCEZV constitutes a social subject made up by social heterogeneity, associated in identity to Emiliano Zapata, general from the Mexican Revolution of 1910. Emiliano Zapata for the peasants of UCEZV "represents the struggle of the dispossessed against the interests of the privileged class; it is also -particularly since the Zapatista uprising in Chiapas- a struggle for dignity, in favor of land" (Hernández et al., 2013: 101).

The creation of a collective identity was configured with the constitution of the UCEZV, as well as a consensus of a diversity of social agents of rejection to the PM, on the basis of bonds of friendship, solidarity and family in the scope of rural communities. The social participation in the SM is not limited to peasants; other actors who participate actively are ejidatarios, small-scale owners, residents, day laborers, small-scale traders, men and women who make theirs the demand for cancellation of the PM. These social sectors share the living space with peasants, with whom they maintain a relationship and certain social cohesion as an expression of local community and organizational practices in the formation of a sense of place; however, because they are also part of forms of dominion and social and political exclusion, they share the feeling of an authoritarian government, angered by the government's way of acting.

A factor that animates and broadens social participation in the SM is the demonstration of the existence of the PM, which as was pointed out at the beginning was systematically denied by the government of the state of Puebla. In April, 2001, members of the UCEZV obtained a document from the SCT where the strategic proposals for sustainable regional development of the PM were exposed, which certainly considered real estate, tourism and industrial development in the region.

The confirmation of the existence of the PM, the authoritarian form of implementing it, and the risible prices that were paid for the land deepened the rejection to the PM and the social indignation, constituting a motor for the mobilization and social participation. 
indignación social, la cual constituye un motor para la movilización y la participación social.

En el anterior marco, miembros y líderes de la UCEVZ renuncian al Partido Revolucionario Institucional (PRI) y exhortan a los campesinos a abandonarlo argumentando, en voz de uno de sus principales dirigente, que los gobiernos priistas «sólo se han dedicado a robar" y se han olvidado de los campesinos (La Jornada, 23 de mayo 2001).

Los campesinos y habitantes de la región del PM fueron base social del sistema político dirigido por el PRI, subordinado históricamente al Estado, que a principios de siglo pasado los había dotado, con la reforma agraria, de la tierra, y corporativizado en la Confederación Nacional Campesina (CNC). Pese al cambio de gobierno federal en el 2000, con la llegada del Fox a la presidencia, el PRI siguió manteniendo bastiones de control político y poder en diferentes gobiernos estatales entre ellos el de Puebla. En el ámbito regional se expresaba en el control de las presidencias municipales y auxiliares.

El rompimiento y rebeldía política de los campesinos a través del MS debilita el campo de poder regional pero no lo elimina. El campo de poder se ejerció a través de estructura de gobierno y de las autoridades agrarias, de la región, que instigaron a los campesinos para la venta de la tierra y apoyaron activamente la difusión del PM, con los supuestos beneficios de empleo e ingresos para los habitantes e hijos de las familias campesinas.

La identidad colectiva de la UCEZV se afirma con el conflicto social con el gobierno del estado de Puebla, la desigualdad y la exclusión. La negación del PM, por el gobierno del estado, su instrumentación autoritaria y clientelar profundizan el rechazo al PM, con un sentido social colectivo de agravio, engańo, irritación y desconfianza, acrecentando la indignación social y la participación social de una diversidad de agentes sociales que comparten estos sentimientos.

Así, el conflicto social entre la UCEZV y el gobierno del estado de Puebla, que impulsa el PM, es una relación contenciosa por la apropiación de un recurso, la tierra, que es valorado en forma diferenciada, para los campesinos significa un modo de vida y un territorio construido socialmente, pero también encarna una crítica social y política, por diversos actores sociales que participan en el MS, a la actuación gubernamental autoritaria, engañosa y coercitiva.
In this framework, membersand leaders of UCEVZ renounce from the Institutional Revolutionary Party (Partido Revolucionario Institucional, PRI) and urge the peasants to abandon it by arguing, as said by one of its main leaders: that PRI governments "have just been devoted to stealing" and have forgotten about the peasants (La Jornada, 23 de mayo 2001).

The peasants and residents of the region of the PM were the social base of the political system led by the PRI, historically subordinate to the State, which at the beginning of the last century had been allotted with land, with the agrarian reform, and became corporative in the National Peasant Confederation (Confederación Nacional Campesina, CNC). Despite the change in federal government in the year 2000, with the arrival of Fox to the presidency, PRI continued to maintain strongholds of political control and power in different state governments, among them Puebla's. In the regional sphere, this was expressed in the control of the municipal presidencies and auxiliaries.

The political split and rebelliousness of peasants through the SM weakens the field of regional power but does not eliminate it. The field of power was exerted through the government structure and the agrarian authorities of the region, which instigated peasants to sell the land and actively supported the diffusion of the PM, with the supposed benefits of employment and income for residents and children of the peasant families.

The collective identity of the UCEZV was affirmed with the social conflict with the state of Puebla, inequality and exclusion. The denial of the PM by the state government, its authoritarian implementation and client politics deepen the rejection to the PM, with a collective social sense of insult, deceit, irritation and mistrust, increasing social indignation and social participation of a diversity of social agents who share these feelings.

Thus, the social conflict between the UCEZV and the state of Puebla's government, which drives the PM, is a contentious relationship for the appropriation of a resource, land, which is valued in a differential way; for the peasants it represents a lifestyle and a socially constructed territory, but also embodies a social and political criticism by various social actors who participate in the SM, to the government's authoritarian, deceitful and coercive acting. 


\section{El conflicto social y la construcción de un proyecto alternativo}

La UCEZV si bien tiene una demanda específica de la cancelación del PM, en medio del conflicto con el gobierno del estado de Puebla, define acciones emergentes en torno a un proyecto alternativo de desarrollo rural y la la lucha por las presidencias municipios de la región.

El proyecto de desarrollo rural alternativo, por la UCEZV, es formulado para responder a la acusación por el gobierno del estado de Puebla de oponerse al progreso, a la industria. El gobernador inculpó a la UCEZV en los siguientes terminos:

"de toda la entidad, la única región que se ha opuesto a la llegada de inversionistas es Tepeaca. Pasado el tiempo, en Actipan -junta auxiliar de Tepeaca y tierra de Concepción Colotla, dirigente de la UCEZV, principal opositor al Millenium- se van a arrepentir de no tener una fábrica”. La Jornada de Oriente, 4 de junio de 2001.

En respuesta, los campesinos argumentaron que no se oponen al progreso de la región, pero no a partir de la industria sino de la agricultura. Esta posición se profundiza a partir de la reflexión y debate sobre las consecuencias del PM en la región Tepeaca-Tecamachalco, con la realización, el 24 de mayo de 2001, del Foro Nacional Permanente contra el Plan Puebla Panamá ${ }^{2}$ el PM, con asociaciones campesinas y civiles de Puebla, estado de México, Veracruz y el Partido de la Revolución Democrática (PRD).

La UCEZV a partir de la relación con organizaciones y movimientos sociales teje una amplia alianza, es particularmente significativa con los ejidatarios de Atenco ${ }^{3}$, que se oponen a la construcción de un aeropuerto internacional en Texcoco, en el Estado de México. La alianza con el PRD es especialmente con el Diputado Local Teodoro Lozano ${ }^{4}$, quien les proporcionó cobertura política, asesoría jurídica y organizativa, así como una relación estrecha con la dirección nacional del partido.

Esta ruta de alianzas y compartir experiencias permite visualizar a la UCEZV, que el PM era parte de un proceso amplio de reorganización territorial del sureste mexicano, que transformaría radicalmente las relaciones sociales y comunitarias, comandado por

\section{Social conflict and the construction of an alternative project}

Although the UCEZV has a specific demand for the cancellation of the PM, in the midst of the conflict with the government of the state of Puebla, it defines emergent actions around an alternative project for rural development and the struggle over municipal presidencies in the region.

The project for alternative rural development by the UCEZV is formulated to respond to the accusation by the state of Puebla's government of opposing progress and industry. The governor accused the UCEZV in the following terms:

"of the entire state, the only region that has opposed the arrival of investors is Tepeaca. After some time, in Actipan -auxiliary board of Tepeaca and land of Concepción Colotla, leader of the UCEZV, main opposition to Millenium- they will regret not having a factory". La Jornada de Oriente, 4 de junio de 2001.

As a response, the peasants argued that they do not oppose progress in the region, but not one based on industry but rather on agriculture. This posture is deepened based on the reflection and debate about the consequences of the PM in the TepeacaTecamachalco region, by holding the Permanent National Forum against the Puebla Panama Plan ${ }^{2}$ and the PM, on May 24, 2001, with peasant and civil associations from Puebla, Estado de México, Veracruz and the Democratic Revolution Party (Partido de la Revolución Democrática, PRD).

The UCEZV, based on the relationship with organizations and social movements, weaves a broad alliance, which is particularly significant with ejidatarios from Atenco $^{3}$, who oppose the construction of an international airport in Texcoco, in Estado de México. The alliance with PRD is in particular with the Local Representative Teodoro Lozano ${ }^{4}$, who provided political support, legal and organizational counseling, as well as a close relationship with the national leadership of the party.

This route or alliances and sharing experiences allows making evident for the UCEZV that the PM was part of a broad process of territorial reorganization of the Mexican southeast, which would radically 
grandes capitales y el Estado mexicano. Consideración que les lleva a emprender una reflexión interna sobre el tipo de desarrollo acorde a sus intereses y expectativas, discusión que les permite afianzar la concepción de un desarrollo regional basado en la agricultura y sus múltiples funciones.

Así, en junio de 2001, llevan al congreso estatal la demanda de apoyo a la agricultura con tecnologías y sistemas de riego. $\mathrm{Y}$, en agosto del mismo año, en alianza con el PRD, se formula un proyecto de desarrollo rural para la región denominado "Programa para un Desarrollo Sustentable en la Región Tepeaca-Tecamachalco" (UCEZV, 2002). El Programa es elaborado a través de una amplia consulta y participación a las comunidades rurales, y considera cuatro ejes prioritarios: ordenamiento ecológico territorial; fortalecimiento de la economía rural basada en la agricultura, desarrollo social y mejoramiento de la infraestructura productiva, con el objetivo de promover un desarrollo sustentable y beneficiar a los pobladores. El Programa de desarrollo expresa un posicionamiento en torno a una vía de desarrollo agrícola y rural para la región, enfrentando la concepción de representación del espacio del PM.

El Programa de desarrollo no es apoyado por el gobierno del estado de Puebla. Empero, la propuesta de desarrollo rural establece un signo que los diferencia de otros MS (Favela, 2017), al plantear alternativas de desarrollo territorial, buscando un presente y futuro mejor, y se convierte en un elemento de lucha al disputar la representación del espacio al gobierno del estado de Puebla.

La anterior acción estratégica se articula a la lucha por la democracia en los municipios de la región. La UCEZV resuelve participar en las elecciones municipales de finales de 2001 con el objetivo de fragmentar el poder político del gobierno del estado de Puebla en la región, en alianza con el Partido Acción Nacional (PAN) y el PRD. El resultado fue el posicionamiento de miembros de la UCEZV en Juntas Auxiliares y ayuntamientos de Tecamachalco, Tepeaca, Tecali y Mixtla. El posicionamiento político de la UCEZV en los gobiernos municipales logró disminuir al priismo, acumular fuerzas y ampliar su influencia entre la población.

La UCEZV, en los municipios donde logró nombrar autoridades, promovió un gobierno desde las bases, cuya mejor expresión es en el municipio de Mixtla al considerar que "las decisiones que asuma el transform the social and community relationships, commanded by large capitals and the Mexican State. This consideration leads them to begin an internal reflection about the type of development according to their interests and expectations, discussion that allows them to secure the conception of a regional development based on agriculture and its multiple functions.

Thus, in June 2001, they took to the state congress the demand for support to agriculture with technologies and irrigation systems. And, in August of the same year, in alliance with PRD, a project for rural development for the region, called "Program for Sustainable Development in the Tepeaca-Tecamachalco Region" (Programa para un Desarrollo Sustentable en la Región TepeacaTecamachalco), was formulated (UCEZV, 2002). The Program was elaborated through large consultation and participation of rural communities, and considers four priority axes: ecological territorial planning; strengthening of rural economy based on agriculture, social development and improvement of productive infrastructure, with the objective of promoting sustainable development and benefiting inhabitants. The development Program expresses a positioning around a path of agricultural and rural development for the region, opposing the conception of representation of space in the PM.

The development Program was not supported by the government of the state of Puebla. However, the proposal for rural development established a sign that differentiates them from other SM (Favela, 2017), when suggesting alternatives for territorial development, seeking a better present and future, and becomes an element of struggle when disputing the representation of space from the government of the state of Puebla.

This strategic action articulated the struggle for democracy in the municipalities of the region. The UCEZV decided to participate in the municipal elections of the end of 2001 with the objective of fragmenting the political power of the state of Puebla's government in the region, in alliance with the National Action Party (Partido Acción Nacional, PAN) and PRD. The result was positioning members of the UCEZV in auxiliary boards and local governments of Tecamachalco, Tepeaca, Tecali and Mixtla. The political positioning of the UCEZV in municipal governments managed to decrease PRI 
ayuntamiento serán consensuadas en asambleas comunales, no en acuerdos de Cabildo" ". La propuesta es de una democracia participativa, directa, que muy pronto choca con la improvisación de los cuadros y la cooptación de los liderazgos y funcionarios de gobierno municipal por el gobierno del estado. En algunos municipios las autoridades nombradas traicionaron al movimiento, mientras en otras posibilitaron obras sociales. Por ejemplo, en San Pablo Actipan, Junta Auxiliar de Tepeaca, el candidato de la UCEZV ganó la votación de la presidencia, pero negoció con el gobierno del estado que promovería el PM.

La UCEZV con la lucha por la democracia cuestiona el sistema político autoritario, a las formas de control político y la democracia representativa. Intenta construir una democracia directa, participativa en la gestión municipal. La UCEZV no sólo rechaza la instrumentación del PM, sino en el trascurso del movimiento construye un poder que disputa el control y dominio político de la región, se constituye en un sujeto con derecho a decidir sobre su condición y futuro de vida en el terreno social y político.

La UCEZV participa en política, haciendo un nuevo tipo de política, intentando fundar gérmenes de una nueva cultura política en la región, fuera del dominio corporativo partidario pero sus alances son limitados. En este sentido, De Sousa (2001: 181) sostiene que la novedad de los nuevos movimientos sociales "no reside en el rechazo de la política sino, al contrario en la ampliación de la política hasta más allá del marco liberal de la distinción entre estado y sociedad civil".

El conflicto social asume de esta manera una interacción contenciosa entre la UCEZV y el gobierno del estado de Puebla, con concepciones diametralmente opuestas sobre la organización espacial de la región Tepeaca-Tecamachalco, a partir de la cual movilizan y organizan los recursos. La UCEZV no solo desarrolla la lucha por la tierra, sino por mantener y desarrollar un modo de apropiación y construcción territorial, articulando la lucha social y política, en la perspectiva de plantear un desarrollo propio, sustentado en la agricultura. Estas acciones son definidas en el conflicto, no están previamente establecida como elementos de una estrategia.

La UCEZV al igual que otros movimientos sociales promueven un nuevo patrón de organización del espacio geográfico, donde surgen nuevas prácticas y relaciones sociales (Porto, 2001). Como sostiene Zibechi (2003: 187) "el territorio es el espacio en el que influence, accumulate strength, and increase its influence in the population.

In the municipalities where it did name authorities, the UCEZV promoted a grassroots government, whose best expression is in the municipality of Mixtla when considering that "the decisions made by the local government will be consensual through communal assemblies, not agreements in the town council"s. The proposal is that of a participative, direct democracy that quite soon clashes with the improvisation of the bases and the cooptation of leaderships and officials of the municipal government by the state government. In some municipalities the authorities appointed betrayed the movement, while in others they made possible social works. For example, in San Pablo Actipan, Auxiliary Board of Tepeaca, the candidate of the UCEZV won the election to the presidency, but negotiated with the state government that the PM would promote.

With its struggle for democracy, the UCEZV questions the authoritarian political system, the forms of political control, and representative democracy. It attempts to build a direct, participative democracy in municipal management. The UCEZV not only rejects the implementation of the PM, but throughout the movement it builds a power that disputes the political control and dominion of the region; the organization is constituted into a subject with a right to decide about living conditions and its future in the social and political terrain.

The UCEZV participates in politics, making a new type of politics, attempting to sow the seeds of a new political culture in the region, outside the party corporate dominion but its reaches are limited. In this sense, De Sousa (2001: 181) maintains that the novelty of new social movements "does not reside in the rejection of the policy, but rather in broadening politics beyond the liberal framework of the distinction between state and civil society".

Social conflict assumes in this way a contentious interaction between the UCEZV and the government of the state of Puebla, with diametrically opposite conceptions about the spatial organization of the Tepeaca-Tecamachalgo region, from which they mobilize and organize the resources. The UCEZV does not only develop the struggle over land, but also maintains and develops a mode of territorial appropriation and construction, articulating the social and political struggle within the perspective 
se construye colectivamente una nueva organización social, donde los nuevos sujetos se instituyen, instituyendo su espacio, apropiándoselo material y simbólicamente".

\section{La movilización social y la cancelación del PM}

La UCEZV, en su confrontación con el gobierno del estado, construyó una ruta que los llevó de una demanda específica, la cancelación del PM, a la elaboración de un proyecto alternativo de desarrollo rural y disputar el poder político regional. En este proceso el gobierno del estado de Puebla fue ampliamente cuestionado en su capacidad para imponer por la vía del autoritarismo y la coerción el PM.

El gobierno del estado de Puebla, inicialmente, argumentó que se trataba únicamente de la construcción de la carretera y por ello la compra de tierras, versión que no reconoció la UCEZV por las evidencias que reunió de la existencia del PM. A partir de las evidencias sobre el PM, la UCEZV inició una amplia difusión en las comunidades y la realización de manifestaciones en la región y la ciudad de Puebla, capital del estado. La respuesta por el gobierno del estado fue la violencia, que se tradujo en la captura de uno de sus líderes y órdenes de aprehensión para otros dirigentes.

En este marco de movilizaciones sociales, el poder e influencia creciente de la UCEZV y el fracaso del ejercicio tradicional del poder para imponer el PM; el gobierno del estado de Puebla reelabora su estrategia, sin abandonar la coerción, e intenta construir cierto consenso entre la población de la región Tepeaca-Tecamachalco de aceptación del PM a través de la estructura de poder regional, como se señaló anteriormente. Así, propone un referéndum sobre la realización del PM, en julio de 2001, propuesta que es rechazada por la UCEZV al considerarlo una farsa. Un año más tarde, en julio de 2002, plantea someter a consulta el PM y el proyecto alternativo formulado por la UCEZV entre la población para decidir cuál instrumentar, propuesta rechazada por la UCEZV. Así mismo, el gobierno del estado promovió, en marzo de 2002, que el Congreso del Estado, dominado por el priismo, declare de utilidad púbica el Proyecto Millenium, con lo cual se estaría en condiciones de expropiar los terrenos, iniciativa que no prosperó. of suggesting its own development, sustained on agriculture. These actions are defined in the conflict, they are not previously established as elements as elements of a strategy.

The UCEZV, similar to other social movements, promotes a new pattern of organization of the geographic space, where new practices and social relationships emerge (Porto, 2001). As Zibechi (2003: 187) states: "the territory is the space where a new social organization is collectively constructed, where the new subjects are introduced, instituting their space, appropriating it materially and symbolically".

\section{Social mobilization and the cancellation of the PM}

The UCEZV, in its confrontation with the state government, built a route that led them from a specific demand, the cancellation of the PM, to the elaboration of an alternative project for rural development and to dispute the regional political power. In this process the government of the state of Puebla was widely questioned in its ability to impose the PM via authoritarianism and coercion.

The government of the state of Puebla initially argued that the conflict was solely about the construction of the highway and therefore the purchase of land, version that the UCEZV did not recognize due to the evidences it gathered about the existence of the PM. Based on the evidences on the PM, the UCEZV began communicating broadly in the communities and performing demonstrations in the region and the city of Puebla, state capital. The response from the state government was violence, which translated into the capture of one of the organization's leaders and arrest warrants for other leaders.

Within this framework of social mobilizations, the growing power and influence of the UCEZV, and the failure of traditional exercise of power to impose the PM, the government of the state of Puebla reworked its strategy, without abandoning coercion and attempting to build certain consensus of acceptance of the PM among the population of the TepeacaTecamachalco region through the regional structure of power, as was previously pointed out. Thus, it proposed a referendum about the implementation of the PM, in July 2001, proposal that was rejected by the UCEZV because it was considered a farce. One 
En el anterior marco de relaciones de fuerza social y política, el MS tiene la mayor participación social, pero también su radicalización, uno de sus principales líderes declaró que 14 pueblos de la región, reaccionarían violentamente si se mantiene el $\mathrm{PM}^{6}$.

El gobierno del estado, al ser desbordado en su estrategia, cede y establece una mesa de negociación, situación que empata con la cancelación del aeropuerto internacional en Texcoco, Estado de México, por el gobierno federal bajo la presión del movimiento social de Atenco. El resultado de la negociación, hacia mediados de septiembre de 2002, fue la cancelación de 13 órdenes de aprehensión; la devolución de las tierras compradas a 137 ejidatarios; la ejecución de obras públicas en los municipios afectados y la solicitud para elaborar una propuesta de desarrollo sustentable para la región centro- oriente de Puebla. Sin embargo, es hasta finales del 2002 que se pactó un acuerdo explícito para cancelar el PM, de nuevo frente a la movilización de la UCEVZ.

Con la cancelación del PM terminó la pretensión del gobierno del Estado de apropiarse, organizar y construir una territorialidad específica. Por su parte, la UCEZV fundó gérmenes de una nueva cultura política en el ámbito regional, fuera del sistema de partidos políticos, vertiente de la acción colectiva articulada a la elección de un modo de vida y defensa del territorio. Ambas líneas de acción fracturaron la forma tradicional de ejercer el dominio y el poder sobre los campesinos.

A partir de la cancelación del PM, la UCEZV se mantiene, manifestándose frente a las acciones gubernamentales que afecten el modo de vida campesino, solidarios con otros movimientos sociales y manteniendo la memoria colectiva viva, pero sin la vitalidad y participación social que se mostró durante el conflicto. Así, la UCEZV se encuentra en la disyuntiva de definir un nuevo ciclo de acción colectiva, con un proyecto de desarrollo rural territorial que atienda los problemas económicos, sociales y políticos de los campesinos y población de la región, a partir de la experiencia, poder y la legitimidad ganada como movimiento social.

\section{CONCLUSIONES}

El conflicto entre los campesinos y el PM entrañó el enfrentamiento de dos proyectos de organización territorial, el de los campesinos que definen y eligen un modo de vida, y el espacio de representación del year later, in July 2002, it suggested subjecting the $\mathrm{PM}$ and the alternative project formulated by the UCEZV to consultation among the population to decide which to implement, proposal that was rejected by the UCEZV. Likewise, the state government promoted, in March 2002, for the Congress of the State dominated by the PRI regime to declare the public utility of the Proyecto Millenium, with which it would be in conditions to expropriate the lands, an initiative that did not succeed.

In this framework of relationships between social and political strength, SM have the greatest social participation, but also its radicalization, one of its principal leaders declared that 14 towns of the region would react violently if the PM were maintained ${ }^{6}$.

The state government, when it was overwhelmed in its strategy, conceded and established a negotiation table, situation that coincided with the cancellation of the international airport in Texcoco, Estado de México, by the federal government under pressure from the Atenco social movement. The result of the negotiation, toward the middle of September 2002, was the cancellation of 13 arrest warrants; the return of lands purchased from 137 ejidatarios; the execution of public works in the municipalities affected and the request to elaborate a proposal of sustainable development for the center-eastern region of Puebla. However, it was not until the end of 2002 that an explicit agreement was made to cancel the PM, again facing the mobilization of the UCEVZ.

With the cancellation of the PM the intent of the state government to appropriate, organize and build a specific territoriality was finished. In turn, the UCEZV sowed the seeds of a new political culture in the regional sphere, outside political parties, aspect of collective action articulated to the choice of a lifestyle and defense of the territory. Both lines of action fractured the traditional way of exerting dominion and power on peasants.

Since the cancellation of the PM, the UCEZV has remained, manifesting against government actions that affect the peasant lifestyle, solidary with other social movements and maintaining the collective memory alive, but without the vitality and social participation that was shown during the conflict. Thus, the UCEZV is found in the dilemma of defining a new cycle of collective action, with a project for territorial rural development that addresses the economic, social and political problems 
gobierno del estado de Puebla, orientado hacia la industria y desarrollo inmobiliario. El modo de vida campesino se fundó en la valoración de la agricultura y los recursos disponibles de tierra y agua; elección de vida construida en oposición crítica a un modelo de desarrollo representado por el PM, constituyendo un elemento central de la identidad social del sujeto, conjuntamente con la memoria histórica del zapatismo sobre la lucha por la tierra. La formación del sujeto social se forja sobre elementos materiales y subjetivos que se retroalimentan y definen sus alcances en el conflicto con el gobierno del estado de Puebla.

El MS en un sentido más amplio es una crítica social a la actuación gubernamental por un colectivo de actores sociales articulados por la UCEZV. En este sentido, en el MS participan actores sociales que no necesariamente comparten la identidad colectiva de la UCEZV pero si el agravio y la indignación por la forma autoritaria, coercitiva y engañosa de la actuación gubernamental.

Un elemento que distingue el MS de la UCEZV es la capacidad para reflexionar sobre sí mismo y sus alcances, logrando la articulación de la lucha por la democracia social y política, definiendo un rumbo propio de desarrollo rural territorial. La UCEZV se afirma como sujeto de derechos sociales y políticos.

En la contribución del movimiento social a un desarrollo rural alternativo destaca: a) la imperiosa necesidad de construir procesos e instituciones inclusivos y de participación social y política de la población en las decisiones gubernamentales; b) la importancia de la participación social en la construcción de vías de desarrollo desde la perspectiva de los actores sociales involucrados, que para el caso concreto del estudio es una vía rural claramente campesina, sobre la base de la agricultura, valoración opuesta a la concepción de considerar a la industria y lo urbano como el camino de la modernización y solución del atraso y la pobreza. Esta vía de desarrollo rural es una lucha por la democracia y el reconocimiento de los derechos sociales y políticos de la población. La agricultura y del desarrollo rural son plenamente vigentes en la lucha contra la exclusión, social y política, y de la pobreza rural que viven amplios sectores de la población en México.

\section{NOTAS}

${ }^{1}$ El trabajo de Vázquez et al. (2010) sobre la UCEZV expone sistemáticamente testimonios sobre la valoración of peasants and population of the region, based on the experience, power and legitimacy earned as a social movement.

\section{CONCLUSIONS}

The conflict between peasants and the PM entailed the confrontation of two projects for territorial organization, that of the peasants who defined and chose a lifestyle, and the representation space of the government of the state of Puebla, directed toward industry and real estate development. The peasant lifestyle was founded in the valuation of agriculture and the available resources of land and water; life choice built into critical opposition to a development model represented by the PM, constituting a central element of the social identity of the subject, jointly with the historical memory of Zapatismo regarding the struggle over land. The formation of the social subject is forged on material and subjective elements that are fed into and define their reaches in the conflict with the government of the state of Puebla.

The SM in a broader sense is a social criticism of the government action by a collective of social actors articulated by the UCEZV. In this sense, social actors participate in the SM who do not necessarily share the collective identity of the UCEZV, but they do share the grievance and indignation from the authoritarian, coercive and deceitful way of government action.

An element that distinguishes the SM of the UCEZV is the ability to reflect about themselves and their reaches, achieving the articulation of the struggle over social and political democracy, defining a path of their own for territorial rural development. The UCEZV is affirmed as a subject of social and political rights.

In the contribution of the social movement to an alternative rural development, the following stand out: a) the imperative need to build inclusive processes and institutions of social and political participation in governmental decisions; b) the importance of social participation in the construction of development paths from the perspective of the social actors involved, which for the concrete case of the study is a clearly peasant rural pathway, based on agriculture, which is the opposite valuation to the conception of considering the industry and the urban as the path of modernization and solution of backwardness and poverty. This rural development 
de la agricultura por los campesinos y la diversidad de actores sociales participantes en el movimiento social. * The study by Vázquez et al. (2010) about the UCEZV systematically exposes testimonies about the valuation of agriculture by peasants and the diversity of social actors who participate in the social movement.

${ }^{2}$ El Plan Puebla Panamá fue un proyecto de los gobiernos de México y Centroamérica, anunciado oficialmente en junio de 2001 en San Salvador, El Salvador, con el propósito de integrar al mercado mundial el sur-sureste de México y Centroamérica (Hiernaux, 2002). The Puebla-Panama Plan was a project of the governments of Mexico and Central America, officially announced in June 2001, in San Salvador, El Salvador, with the purpose of integrating the south-southeast of Mexico and Central America into the global market.

${ }^{3}$ El gobierno federal, en octubre de 2001, emitió diecinueve decretos expropiatorios para la construcción de un nuevo aeropuerto internacional en la zona de Texcoco, estado de México. A esta decisión gubernamental se resistieron ejidatarios y habitantes que formaron el movimiento social de Atenco. Este movimiento social desplegó una intensa movilización social y acciones jurídicas para oponerse a las expropiaciones y exigir la cancelación del aeropuerto, que finalmente logró en agosto de 2002 (Kuri, 2010). * The federal government issued nineteen expropriation decrees in October 2001, for the construction of a new international airport in the zone of Texcoco, Estado de México. Ejidatarios and inhabitants who formed the Atenco social movement resisted this government decision. This social movement deployed an intense social movement and legal actions to oppose the expropriations and demand the cancellation of the airport, which it finally achieved in August 2002 (Kuri, 2010).

${ }^{4}$ El Diputado Lozano falleció como consecuencia de un accidente carretero ocurrido durante agosto del 2001, la UCEZV responsabilizó al gobierno estatal del accidente e incorporó entre sus demandas el esclarecimiento de su muerte. The Representative Lozano died as consequence of a car accident that happened during August 2001; the UCEZV accused the state government of being responsible for the accident and incorporated among its demands the clarification of his death.

${ }^{5}$ La Jornada de Oriente, 28 de diciembre de 2001. path is a struggle for democracy and the recognition of social and political rights of the population. Agriculture and rural development are fully current in the struggle against exclusion, social and political, and rural poverty experienced by broad sectors of the population in Mexico.

- End of the English version-

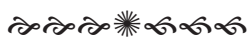

La Jornada de Oriente, December 28, 2001.

${ }^{6}$ La Jornada de Oriente, 6 de mayo de 2002. La Jornada de Oriente, May 6, 2002.

\section{LITERATURA CITADA}

Bebbington, Anthony. 1999. Capitals and Capabilities: A Framework for Analyzing Peasant Viability, Rural Livelihoods and Poverty. In: World Development 27, no. 12.

De Sousa Santos, B. 2001. Los nuevos movimientos sociales. Observatorio Social de América Latina, no. 5. Consejo Latinoamericano de Ciencias Sociales (CLACSO). Disponible en: http://biblioteca.clacso.edu.ar/ar/libros/osal/osal5/debates.pdf

Favela Gavia, Margarita. 2017. Proyectos políticos y prácticas estratégicas de los movimientos de protesta en México en el siglo XXI. In: Francisco Javier Aguilar García (coord). Movimientos sociales en México y Latinoamérica. UNAM, Instituto de Investigaciones Sociales. México.

Garavaglia, Juan Carlos, y Grosso, Juan Carlos. 1994. Puebla desde una perspectiva microhistórica: Tepeaca y su entorno agrario: población, producción e intercambio (1740-1870). Claves Latinoamericanas. México.

Giménez, Gilberto. 2000. Materiales para una teoría de las identidades sociales. In: Juan Manuel Valenzuela Arce (coord). Decadencia y auge de las identidades. El Colegio de la Frontera Norte/Plaza y Valdés Editores. México, D.F.

Harvey, David. 2007. Breve historia del neoliberalismo. Akal. Madrid

Hernández Flores, José Álvaro, Martínez Corona Beatriz, y Ramírez Juárez, Javier. 2013. Sujetos sociales en la defensa del territorio en Puebla, México: La Unión Campesina Emiliano Zapata Vive. Agricultura, Sociedad y Desarrollo. Volumen 10, Número 1.

Hernández Flores, José Álvaro. 2009. Resistencia territorial, cambios identitarios y conformación de nuevos sujetos sociales en el campo. La experiencia de la Unión Campesina Emiliano Zapata Vive (Puebla, México). In: Fabio Lozano Velásquez y Juan Guillermo Ferro Medina (eds). Las configuraciones de los territorios rurales en el siglo XXI. Pontificia Universidad Javeriana. Bogotá.

Hiernaux Nicolas, Daniel. 2002. El Plan Puebla Panamá: ¿una nueva visión del desarrollo regional? Conférence prononcée le 17 septembre 2002, Québec. Disponible en: http://www. ieim.uqam.ca/IMG/pdf/PPP-Hiernaux-final.pdf 
Kuri Pineda, Edith. 2010. El movimiento social de Atenco: experiencia y construcción de sentido. Andamios, 7 (14). Disponible en: http://www.scielo.org.mx/scielo.php?script=sciar ttext\&pid=S1870-00632010000300013

Lefebvre, Henri.1974. La producción del espacio. Papers. Revista De Sociología, 3, 219-229.

Lomelí Vanegas, Leonardo. 2001. Breve historia de Puebla. Fondo de Cultura Económica / El Colegio de México. México.

Melucci, Alberto. 1999. Acción colectiva, vida cotidiana y democracia. El Colegio de México. México.

Nickel, Herbert. 2004. Los trabajadores agrícolas en la revolución mexicana (1910-1940): algunas hipótesis y datos sobre la participación y la no participación en los Altos de PueblaTlaxcala. In: Friedrich Katz (comp) Revuelta, rebelión y revolución. La lucha rural en México del siglo XVI al siglo XX. Ediciones Era. México.

Olivera, Mercedes. 1978. Pillis y macehuales: las formaciones sociales y los modos de producción de Tecali del siglo XII al XVI. Ediciones de la Casa Chata. México.

Porto Gonçalves, Carlos Walter. 2001. Geo-grafías. Movimientos sociales, nuevas territorialidades y sustentabilidad. Siglo XXI. México.

Ramírez Juárez, Javier. 2009. Recomposición agrícola del campesinado en el valle de Tepeaca (Puebla, México). In: Fabio Lozano Velásquez y Juan Guillermo Ferro Medina (eds). Las configuraciones de los territorios rurales en el siglo XXI. Pontificia Universidad Javeriana. Bogotá.
SCT (Secretaría de Comunicaciones y Transportes). 2001. El Programa de Desarrollo Regional Milenium, Puebla 2000. Documento electrónico. Puebla, México.

SIAP (Servicio de Información Agroalimentaria y Pesquera). 2006. Anuario estadístico de la producción agrícola y pecuaria 2005. México.

UCEZV. 2002. Programa para un desarrollo sustentable en la región Tepeaca-Tecamachalco. PRD. México.

Vázquez, Rosalía; Rappo Susana, y Cortés Sergio. 2010. Historia de una lucha. Unión Campesina Emiliano Zapata Vive. BUAP-Educación y Cultura. Puebla, México.

Zepeda Martínez, Roberto. 2017. Neoliberalismo, democratización y movimientos sociales en Latinoamérica. In: Francisco Javier Aguilar García (coord). Movimientos sociales en México y Latinoamérica. UNAM, Instituto de Investigaciones Sociales. México.

Zibechi, Raúl. 2003. Los movimientos sociales latinoamericanos: tendencias y desafíos. In: Observatorio Social de América Latina. No. 9. Consejo Latinoamericano de Ciencias Sociales (CLACSO). Disponible en: http://bibliotecavirtual.clacso. org.ar/ar/libros/osal/osal9/zibechi.pdf

\section{Fuentes periodísticas}

La Jornada de Oriente, 19 de marzo de 2001,

La Jornada de Oriente, 4 de junio de 2001.

La jornada de Oriente 23 de mayo 2001

La Jornada de Oriente, 28 de diciembre de 2001.

La Jornada de Oriente, 6 de mayo de 2002. 